\title{
Effects of single-dose zileuton on bronchial hyperresponsiveness in asthmatic patients treated with inhaled corticosteroids
}

\author{
P.N.R. Dekhuijzen, G.P. Bootsma, P.L.M.L. Wielders, L.R.M. van den Berg, \\ J. Festen, C.L.A. van Herwaarden
}

Effects of single-dose zileuton on bronchial hyperresponsiveness in asthmatic patients treated with inhaled corticosteroids. P.N.R.Dekhuijzen, G.P.Bootsma, P.L.M.L.Wielders, L.R.M. van den Berg, J. Festen, C.L.A. van Herwaarden. CERS Journals Ltd 1997.

ABSTRACT: The aim of the study was to determine whether zileuton, an inhibitor of 5-lipoxygenase, attenuated bronchial hyperresponsiveness (BHR) in asthmatic subjects who had marked BHR during maintenance treatment with inhaled corticosteroids (ICS).

In a randomized, double-blind, placebo-controlled, cross-over study, a challenge test with histamine (provocative concentration of histamine producing a $20 \%$ fall in forced expiratory volume in one second (FEV1) (PC20,Hist)) and with ultrasonically nebulized distilled water (UNDW) (provocative dose of UNDW producing a $20 \%$ fall in FEV1 (PD20,UNDW)) was performed in seven patients with asthma after intake of either $400 \mathrm{mg}$ zileuton or placebo. All patients (mean age 33 yrs, mean FEV1 $111 \%$ of predicted) had marked BHR, as indicated by a mean PD20,UNDW of $4.74 \mathrm{~mL}$ under treatment for at least 6 months with up to $800 \mu \mathrm{g}$ ICS (mean $536 \mu \mathrm{g}$ daily). On four different occasions, separated by at least 5 days, two UNDW and two histamine challenge tests were performed in random order $3 \mathrm{~h}$ after a morning dose of either zileuton or placebo.

Neither zileuton nor placebo changed baseline airway calibre prior to provocation. Zileuton increased PC20,Hist from 0.99 to $5.64 \mathrm{mg} \cdot \mathrm{mL}^{-1}(2.1$ doubling doses; p<0.03 compared to placebo), and increased PD20,UNDW from 3.10 to $9.31 \mathrm{~mL}(1.3$ doubling doses; $p<0.05$ compared to placebo).

In conclusion, a single dose of $400 \mathrm{mg}$ zileuton attenuates bronchial hyperresponsiveness to histamine and ultrasonically nebulized distilled water in asthmatic patients with marked bronchial hyperresponsiveness during treatment with inhaled corticosteroids.

Eur Respir J 1997; 10: 2749-2753.
Dept of Pulmonary Diseases, Academic Hospital Nijmegen, Nijmegen, The Netherlands

Correspondence: P.N.R. Dekhuijzen Dept of Pulmonary Diseases Academic Hospital Nijmegen PO Box 9101 6500 HB Nijmegen The Netherlands

Keywords: Asthma bronchial hyperresponsiveness inhaled corticosteroids lipoxygenase inhibitor zileuton

Received: July 301996

Accepted after revision June 221997

Supported by a grant from Abbott, The Netherlands. Medication supplied by Abbott, The Netherlands.
Current therapy for asthma is aimed at suppressing the inflammatory process in the wall of the airways, thus reducing symptoms of bronchial hyperresponsiveness (BHR) and airways obstruction. Inhaled corticosteroids (ICS) have been shown to be very effective in this respect. This may result in a tendency towards prescribing high doses for prolonged periods of time. In this respect, concerns about the safety of ICS have recently been addressed $[1,2]$. ICS may reduce serum cortisol levels, alter biochemical markers of bone metabolism, and, in children, suppress growth velocity. The longterm clinical significance of these changes is not yet clear.

Other classes of anti-inflammatory agents for the treatment of asthma are currently under investigation. One of these drugs, zileuton $(N-1$-(benzo $(b)$ thien-2-ylethyl)$N$-hydroxyurea), an inhibitor of the 5-lipoxygenase pathway, has been shown to be efficacious in patients with asthma [3-6]. Single-dose studies have shown an attenuation of the asthmatic response to cold dry air [7], but not after allergen challenge [8]. In aspirin-sensitive

For editorial comment see page 2701 asthmatics, $2.4 \mathrm{mg}$ zileuton daily for 1 week prevented the fall in forced expiratory volume in one second (FEV1) in response to ingestion of aspirin [9]. A similar dose, administered for 2 days, attenuated exercise-induced bronchoconstriction [10]. A 13 week treatment period with zileuton, 1.6 or $2.4 \mathrm{mg}$ daily, resulted in a $58 \%$ increase in the cold air minute ventilation required to cause a $15 \%$ decrease in FEV1 [11]. Asthma symptoms and FEV1 improved after 4 [12] to 13 weeks [13] of treatment with a similar dose of zileuton, without clear side-effects [12].

Whether zileuton has an additional effect on BHR in patients already treated with ICS is unknown. Such an action would be of potential clinical relevance, since it would allow tapering of the dosage of ICS. In the present study, this question was addressed by measuring the effect of a single dose of $400 \mathrm{mg}$ zileuton during challenge with histamine (which, in the main, acts directly on airway smooth muscle) and ultrasonically-nebulized distilled water (UNDW) (which induces bronchoconstriction by the release of several mediators) in patients with asthma who were on maintenance treatment with ICS. 


\section{Patients and methods}

\section{Study design}

This study was carried out using a randomized, double-blind, placebo-controlled, cross-over design. Seven patients with asthma according to the American Thoracic Society (ATS) criteria [14], who had marked BHR during treatment for at least 6 months with up to 800 $\mu \mathrm{g}$ ICS, were studied. They were tested on four different occasions separated by at least 5 days within a period of 4 weeks. Two challenge tests with UNDW (provocative dose of UNDW causing a $20 \%$ fall in FEV1) (PD20,UNDW)) and two with histamine (provocative concentration of histamine causing a $20 \%$ fall in FEV1 (PC20,Hist)) were performed in random order $3 \mathrm{~h}$ after an 09:00 $\mathrm{h}$ dose of either zileuton or placebo.

\section{Subjects}

Nonsmoking patients with allergic asthma, who exhibited marked BHR under maintenance treatment with ICS for at least 6 months, were selected. Allergy was defined as an elevated specific immunoglobulin $\mathrm{E}$ (IgE) or a positive skin-prick test for house dust mite or at least two other common aeroallergens [15] Patients were included if their FEV 1 was above $70 \%$ of predicted [16] and PD20,UNDW was below $8 \mathrm{~mL}$. The second criterion was set for two reasons: firstly, from previous studies in our laboratory it appeared that this level of PD20,UNDW was associated with a PC20,Hist of less than $4 \mathrm{mg} \cdot \mathrm{mL}^{-1}[17,18]$; and, secondly, these levels of BHR provide the opportunity for measurable improvement by the drug under investigation. The current use of ICS (beclomethasone dipropionate or budesonide, either by metered-dose inhaler (MDI) or by dry powder) was not allowed to be higher than $800 \mu \mathrm{g}$ daily. All subjects used salbutamol as rescue medication. Patients on long-acting $\beta_{2}$-agonists, theophylline and oral anticoagulative drugs, as well as patients who were pregnant or breast-feeding, were excluded from participation in the study.

A total number of 17 patients, fulfiling the requirements with regard to current medication, were screened to participate. Ten subjects were not enrolled into the study, since the screening UNDW challenge test appeared to be negative. By chance, the seven subjects participating in the study were all female. Laboratory testing (complete blood count, serum chemistry) was performed after each provocation to assess the safety and tolerability of zileuton.

\section{Measurement of lung function and BHR}

Subjects did not use ICS or rescue medication for at least $8 \mathrm{~h}$ before each visit and rested $30 \mathrm{~min}$ before the measurements were started. Baseline FEV1 on the four study days had to be within $10 \%$, otherwise the test was postponed to a later day. Lung function and responses to provocation with histamine and UNDW were assessed by FEV1, measured with a flow-volume curve recorded on a heated pneumotachograph (Spiro analyzer
ST 250®; Fukuda Sangyo Co., Tokyo, Japan). Baseline lung function was recorded as the best of three reproducible values of FEV1 (within 5\%) before the provocation tests.

The same technician from the lung function department always checked the patients morning FEV1. If the patient fulfilled the entry criteria, the technician then delivered the correct tablet according to the randomization list. Randomization was performed in blocks of four prior to the start of the study. For each participant number a sequence of measurements with either tablet "A" of "B" was listed according to the randomization list. The four tests (i.e. A-Hist, A-UNDW, B-Hist, B-UNDW) were sequenced at random. The patients received oral zileuton (capsules, $400 \mathrm{mg}$ ) or placebo capsules of identical appearance (both supplied by Abbott Laboratories) according to a blinded and randomized code. This dose of zileuton was chosen since leukotriene $\mathrm{B}_{4}$ $\left(\mathrm{LTB}_{4}\right)$ production by ex vivo calcium ionophone-stimulated whole blood from healthy volunteers was inhibited by up to $80 \%$ of baseline. This response was studied in dosages of 200, 400, 600 and $800 \mathrm{mg}$ of zileuton, and this reduction appeared to plateau at a dose of 400 $\mathrm{mg}$ [19]. Thus, $400 \mathrm{mg}$ appears to be a dose that might be expected to have some physiological effect.

Three hours after intake, FEV1 was measured again. Subsequently, the provocation tests were performed. The histamine provocation test was carried out according to the method of CосксRоFт et al. [20]. For 2 min, patients inhaled doubling concentrations of histamine acid phosphate by tidal breathing, increasing from 0.03 to $16 \mathrm{mg} \cdot \mathrm{mL}^{-1}$. Histamine was nebulized with a DeVilbiss 646 nebulizer (DeVilbiss, Somerset, PA, USA) with a fixed output of $0.13 \mathrm{mg} \cdot \mathrm{mL}^{-1}$. PC20, Hist was determined in $\mathrm{mg} \cdot \mathrm{mL}^{-1}$ by interpolating the last two points of the dose-response curve on a semilogarithmic scale. Responsiveness to UNDW was assessed according to the method of Groot et al. [17]. UNDW was generated with an ultrasonic nebulizer (Ultraneb 99; DeVilbiss, Somerset, PA, USA) at a fixed output of $2.00 \pm 0.05$ $\mathrm{mg} \cdot \mathrm{mL}^{-1}$. After inhalation of $20 \mathrm{~L}$ of ambient air through the system, patients inhaled doubling volumes of air with $\operatorname{UNDW}(3,5,10$, up to $160 \mathrm{~L})$, measured with a Wright respirometer (British Oxygen Co., London, UK). The respirometer was placed between the aerosol hose and the mouthpiece by means of a two-way valve. Before and after each test, the nebulizer chamber and aerosol hose were weighed to determine the exact amount of distilled water inhaled. The cumulative amount of inhaled water (mL) causing a $20 \%$ fall in FEV1 from post-air values (PD20,UNDW) was calculated by linear interpolation on a semilogarithmic curve.

\section{Statistical analysis}

PC20 and PD20 values were log transformed before analysis and compared by analysis of variance using the Statistical Package for the Social Sciences (SPSS) version 5.0 software [21]. Paired data were analysed using the Wilcoxon signed rank test. Carry-over effects were analysed according to Pocock [22] using the MannWhitney U-test. Results are presented as means and standard errors of the means (SEM). Significance was accepted at a p-value of less than 0.05 . 


\section{Results}

Patient characteristics are summarized in table 1. Their baseline FEV1 ranged $86-134 \%$ pred. The daily use of ICS ranged 200-800 $\mu \mathrm{g}$ daily (mean 536 $\mu \mathrm{g}$ ). Under this medication all patients had marked BHR, as indicated by a mean PD20,UNDW of $4.74 \mathrm{~mL}$ at entry

Table 1. - Patients characteristics at baseline

\begin{tabular}{|c|c|c|c|c|c|c|}
\hline \multirow[t]{2}{*}{$\begin{array}{l}\mathrm{Pt} \\
\text { No. }\end{array}$} & \multirow{2}{*}{$\begin{array}{l}\text { Age } \\
\text { yrs }\end{array}$} & \multirow{2}{*}{$\begin{array}{c}\text { ICS } \\
\mathrm{mg} \cdot \text { day }^{-1}\end{array}$} & \multirow{2}{*}{$\begin{array}{c}\beta_{2} \text { use } \\
\mathrm{mg} \cdot \text { day }^{-1}\end{array}$} & \multicolumn{2}{|c|}{$\begin{array}{l}\text { Prestudy } \\
\text { FEV1 }\end{array}$} & \multirow{2}{*}{$\begin{array}{l}\text { PD20,UNDW } \\
\mathrm{mL}\end{array}$} \\
\hline & & & & $\mathrm{L}$ & $\%$ pred & \\
\hline 1 & 19 & BDP, 400 & 0.1 p.r.n. & 3.53 & 115 & 3.01 \\
\hline 2 & 57 & BDP, 750 & 0.4 p.r.n. & 2.70 & 134 & 7.98 \\
\hline 3 & 36 & BUD, 800 & 0.8 & 2.41 & 86 & 3.61 \\
\hline 4 & 20 & BDP, 200 & 0.4 p.r.n. & 3.17 & 88 & 3.97 \\
\hline 5 & 27 & BUD, 400 & 0.8 & 4.01 & 119 & 5.48 \\
\hline 6 & 27 & BDP, 400 & 0.1 p.r.n. & 3.42 & 111 & 3.18 \\
\hline 7 & 44 & BDP, 800 & 1.6 & 3.00 & 125 & 6.00 \\
\hline Mea & 33 & 536 & & 3.18 & 111 & 4.74 \\
\hline SEM & 5 & 92 & & 0.20 & 7 & 0.69 \\
\hline
\end{tabular}

Pt: patient; ICS: inhaled corticosteroids; $\beta_{2}$ use: mean daily use of $\beta_{2}$-agonist in the previous 6 months; FEV 1 : forced expiratory volume in one second; PD20,UNDW: provocative dose of ultrasonically nebulized distilled water causing a $20 \%$ fall in FEV1 from baseline; BDP: beclomethasone dipropionate; BUD: budesonide.

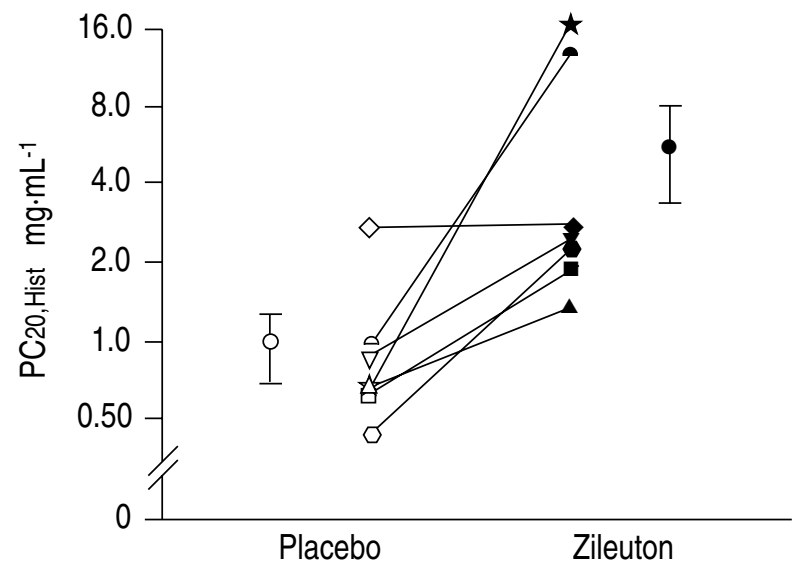

Fig. 1. - Individual data for the provocative concentration of histamine causing a $20 \%$ fall in forced expiratory volume in one second (PC20,Hist) after placebo (open symbols) and zileuton (closed symbols). Values are presented as mean \pm sem, increasing from $0.99(0.29)$ after placebo to $5.64(2.27) \mathrm{mg} \cdot \mathrm{mL}^{-1}$ after zileuton (2.1 doubling doses; $p<0.03)$. The same symbols for individual patients are used in figures 1 and 2 .

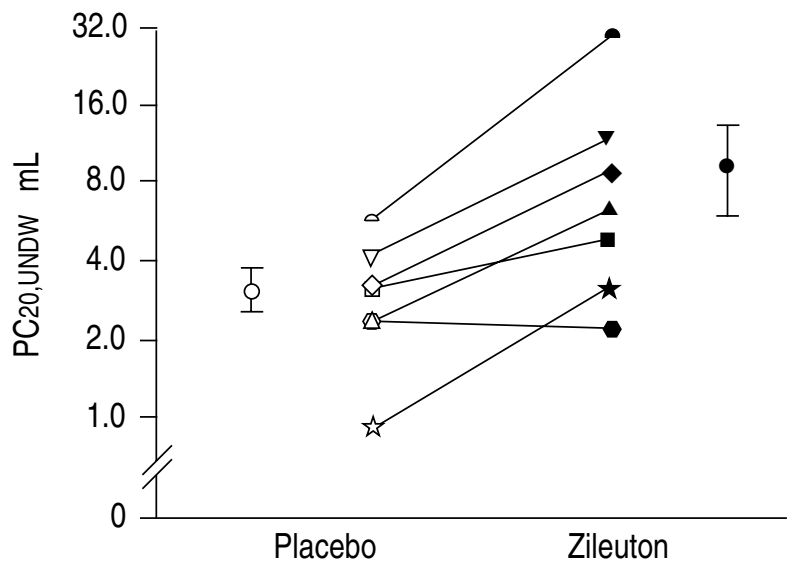

Fig. 2. - Individual data for the provocative dose of ultrasonically nebulized distilled water causing a $20 \%$ fall in forced expiratory volume in one second (PD20,UNDW) after placebo (open symbols) and zileuton (closed symbols). Values are presented as mean \pm SEM, increasing from $3.10(0.56)$ after placebo to 9.31 (3.38) $\mathrm{mL}$ after zileuton $(1.3$ doubling doses; $\mathrm{p}<0.05)$. The same symbols for individual patients are used in figures 1 and 2 .

into the study and a mean PC20,Hist of $0.99 \mathrm{mg} \cdot \mathrm{mL}^{-1}$ after placebo (fig. 1). Zileuton was well tolerated. No haematological or biochemical changes were observed after treatment.

Baseline FEV1 before administration of zileuton or placebo was similar on the four occasions (table 2). Neither zileuton nor placebo changed FEV1 $3 \mathrm{~h}$ after intake. Thus, zileuton did not cause acute bronchodilation in these patients.

Zileuton increased PC20,Hist from 0.99 (0.29) to 5.64 (2.27) $\mathrm{mg} \cdot \mathrm{mL}^{-1}$ (2.1 doubling doses (DD); $\mathrm{p}<0.03 \mathrm{com}-$ pared to placebo) (fig. 1). In six of the seven patients, a clear increase was observed. PD20,UNDW was increased from 3.10 (0.56) to $9.31(3.38) \mathrm{mL}(1.3 \mathrm{DD} ; \mathrm{p}<0.05$ compared to placebo) (fig. 2). Again, an improvement was observed in all but one patient (which was not the same patient as the one that showed no improvement of the PC20,Hist).

To exclude some unexpected order effect, table 3 lists the individual data set out by order of challenge and drug with the gap between the challenges applied. Apparently, no order effect was present; e.g. patients who received zileuton at the last challenge (Nos. 1, 3, 6 and 7) and patients who received placebo at the last challenge (Nos. 2, 4 and 5) both showed improvements

Table 2. - FEV 1 at baseline and at the start of each provocation test

\begin{tabular}{|c|c|c|c|c|c|c|c|c|}
\hline \multirow{3}{*}{$\begin{array}{l}\mathrm{Pt} \\
\text { No. }\end{array}$} & \multicolumn{4}{|c|}{ Zileuton } & \multicolumn{4}{|c|}{ Placebo } \\
\hline & \multicolumn{2}{|c|}{ FEV1 before histamine } & \multicolumn{2}{|c|}{ FEV1 before UNDW } & \multicolumn{2}{|c|}{ FEV1 before histamine } & \multicolumn{2}{|c|}{ FEV1 before UNDW } \\
\hline & $\begin{array}{c}\text { Baseline } \\
\text { L }\end{array}$ & $\begin{array}{c}\text { After } 3 \mathrm{~h} \\
\mathrm{~L}\end{array}$ & $\begin{array}{c}\text { Baseline } \\
\text { L }\end{array}$ & $\begin{array}{c}\text { After } 3 \mathrm{~h} \\
\mathrm{~L}\end{array}$ & $\begin{array}{c}\text { Baseline } \\
\text { L }\end{array}$ & $\begin{array}{c}\text { After } 3 \mathrm{~h} \\
\mathrm{~L}\end{array}$ & $\begin{array}{c}\text { Baseline } \\
\text { L }\end{array}$ & $\begin{array}{c}\text { After } 3 \mathrm{~h} \\
\mathrm{~L}\end{array}$ \\
\hline 1 & 3.58 & 3.53 & 3.76 & 3.54 & 3.68 & 3.52 & 3.78 & 3.59 \\
\hline 2 & 2.65 & 2.71 & 3.04 & 2.98 & 2.73 & 2.40 & 2.80 & 2.83 \\
\hline 3 & 2.42 & 2.35 & 2.50 & 2.39 & 2.32 & 2.30 & 2.31 & 2.47 \\
\hline 4 & 3.22 & 3.30 & 3.12 & 3.32 & 3.19 & 3.24 & 3.13 & 3.05 \\
\hline 5 & 4.03 & 4.01 & 3.79 & 3.67 & 4.04 & 3.69 & 3.99 & 3.56 \\
\hline 6 & 3.51 & 3.71 & 3.75 & 3.86 & 3.57 & 3.77 & 3.71 & 3.76 \\
\hline 7 & 3.03 & 3.13 & 3.14 & 3.36 & 3.15 & 3.29 & 3.17 & 3.11 \\
\hline Mean & 3.21 & 3.25 & 3.30 & 3.30 & 3.24 & 3.17 & 3.27 & 3.20 \\
\hline SEM & 0.21 & 0.22 & 0.19 & 0.19 & 0.22 & 0.22 & 0.23 & 0.17 \\
\hline
\end{tabular}

FEV1: forced expiratory volume in one second; Pt: patient; UNDW: ultrasonically nebulized distilled water. 
Table 3. - FEV1 at baseline and at the start of each provocation test in the sequence of the tests performed

\begin{tabular}{|c|c|c|c|c|c|c|c|c|}
\hline \multirow[b]{2}{*}{$\begin{array}{l}\mathrm{Pt} \\
\text { No. }\end{array}$} & \multicolumn{2}{|c|}{ Visit 1} & \multicolumn{2}{|c|}{ Visit 2} & \multicolumn{2}{|c|}{ Visit 3} & \multicolumn{2}{|c|}{ Visit 4} \\
\hline & $\begin{array}{c}\text { FEV1 } \\
\text { baseline } \\
\text { and after } 3 \mathrm{~h} \\
\mathrm{~L}\end{array}$ & Challenge & $\begin{array}{c}\text { FEV1 } \\
\text { baseline } \\
\text { and after } 3 \mathrm{~h} \\
\mathrm{~L}\end{array}$ & Challenge & $\begin{array}{c}\text { FEV1 } \\
\text { baseline } \\
\text { and after } 3 \mathrm{~h} \\
\mathrm{~L}\end{array}$ & Challenge & $\begin{array}{c}\text { FEV1 } \\
\text { baseline } \\
\text { and after } 3 \mathrm{~h} \\
\mathrm{~L}\end{array}$ & Challenge \\
\hline \multirow[t]{2}{*}{1} & Day 0 & Z-Hist & Day 7 & P-UNDW & Day 14 & P-Hist & Day 21 & Z-UNDW \\
\hline & $3.58 \rightarrow 3.53$ & 1.92 & $3.78 \rightarrow 3.59$ & 3.13 & $3.68 \rightarrow 3.52$ & 0.613 & $3.76 \rightarrow 3.54$ & 4.84 \\
\hline \multirow[t]{2}{*}{2} & Day 0 & P-UNDW & Day 6 & Z-UNDW & Day 13 & Z-Hist & Day 20 & P-Hist \\
\hline & $2.80 \rightarrow 2.83$ & 2.32 & $3.04 \rightarrow 2.98$ & 6.32 & $2.65 \rightarrow 2.71$ & 1.348 & $2.73 \rightarrow 2.40$ & 0.658 \\
\hline \multirow[t]{2}{*}{3} & Day 0 & P-UNDW & Day 7 & P-Hist & Day 13 & Z-Hist & Day 19 & Z-UNDW \\
\hline & $2.31 \rightarrow 2.47$ & 4.2 & $2.32 \rightarrow 2.30$ & 0.875 & $2.42 \rightarrow 2.35$ & 2.497 & $2.50 \rightarrow 2.39$ & 11.7 \\
\hline \multirow[t]{2}{*}{4} & Day 0 & P-Hist & Day 6 & Z-UNDW & Day 12 & Z-Hist & Day 19 & P-UNDW \\
\hline & $3.19 \rightarrow 3.24$ & 2.739 & $3.12 \rightarrow 3.32$ & 8.78 & $3.22 \rightarrow 3.30$ & 2.806 & $3.13 \rightarrow 3.05$ & 3.20 \\
\hline \multirow[t]{2}{*}{5} & Day 0 & Z-Hist & Day 8 & Z-UNDW & Day 15 & P-Hist & Day 22 & P-UNDW \\
\hline & $4.03 \rightarrow 4.01$ & $>16$ & $3.79 \rightarrow 3.67$ & 3.17 & $4.04 \rightarrow 3.69$ & 0.676 & $3.99 \rightarrow 3.56$ & 0.93 \\
\hline \multirow[t]{2}{*}{6} & Day 0 & P-UNDW & Day 5 & P-Hist & Day 12 & Z-UNDW & Day 19 & Z-Hist \\
\hline & $3.71 \rightarrow 3.76$ & 2.35 & $3.57 \rightarrow 3.77$ & 0.438 & $3.75 \rightarrow 3.86$ & 2.20 & $3.51 \rightarrow 3.71$ & 2.273 \\
\hline \multirow[t]{2}{*}{7} & Day 0 & Z-UNDW & Day 7 & P-UNDW & Day 17 & P-Hist & Day 23 & Z-Hist \\
\hline & $3.14 \rightarrow 3.36$ & $>28.2$ & $3.17 \rightarrow 3.11$ & 5.6 & $3.15 \rightarrow 3.29$ & 0.983 & $3.13 \rightarrow 3.13$ & 12.668 \\
\hline
\end{tabular}

Z: zileuton; P: placebo. For further definitions see legend to table 2.

in the level of hyperresponsiveness.

\section{Discussion}

The present study shows that a single dose of $400 \mathrm{mg}$ zileuton improves BHR in asthmatic patients with marked BHR under maintenance treatment with ICS. Indeed, six out of seven patients showed an increase in PC20,Hist after zileuton in comparison to placebo, and, similarly, PD20,UNDW was improved in six of the seven patients. Neither zileuton nor placebo changed airway calibre, as indicated by no changes in FEV 1 during $3 \mathrm{~h}$ after intake.

To assess the efficacy of anti-inflammatory treatment, an indirect challenge (as with UNDW) may be of value since it mimics naturally occurring bronchoconstrictor stimuli and because it reflects the severity of asthma better than pharmacological stimuli [23, 24]. UNDW induces bronchoconstriction by cell-mediated events [24]. Challenge with UNDW may increase BHR and induce a late asthmatic response, just as occurs on exposure to allergens $[25,26]$. The extent of the increase in PD20, UNDW (1.3 DD) in the present study was slightly less than in the study of GROOT et al. [27], who found an increase of $1.8 \mathrm{DD}$ after 4 weeks of beclomethasone dipropionate, $800 \mu \mathrm{g}$ daily. This may be explained by the fact that at baseline the present patients were less responsive to UNDW, the PD20,UNDW being $4.74 \mathrm{~mL}$ (at intake) and $3.1 \mathrm{~mL}$ (after placebo), compared to 1.3 $\mathrm{mL}$ in the study by GROOT et al. [27].

In contrast, inhaled histamine acts, in the main, directly on the airway smooth muscle [23]. The magnitude of increase in PC20,Hist after a single dose of $400 \mathrm{mg}$ zileuton $(2.1 \mathrm{DD})$ resembles the effects of maintenance therapy with ICS in previous studies. The average increase in PC20,Hist or methacholine after chronic treatment with beclomethasone dipropionate or budesonide, as recently reviewed by BARNES and PEDERSEN [28], is about 1-2 DD.

To the best of our knowledge, no single- or multipledose studies have been performed looking directly at histamine or methacholine reactivity after the administration of 5-lipoxygenase inhibitors. With leukotriene receptor antagonists, a small but significant reduction (from 0.30 to $0.48 \mathrm{mg} \cdot \mathrm{mL}^{-1}$ ) in methacholine responsiveness was observed after a 1 week treatment of asth- matic patients with pranlukast [29]. Therefore, the magnitude of the acute effect of zileuton on histamine and UNDW reactivity observed in the present study is difficult to compare with previous data.

The mechanisms by which zileuton attenuates the response to histamine and UNDW in these asthmatics who are being treated with ICS are unknown. Previous studies showed that a single dose of $600 \mathrm{mg}$ zileuton rapidly (i.e. within $1 \mathrm{~h}$ ) increased FEV 1 by $\sim 0.35 \mathrm{~L}$ in patients with an FEV1 of $\sim 57-60 \%$ pred [12]. Such improvement was not observed in other studies $[7,8]$ or in the present patients, presumably because the FEV1 was close to its predicted value in these studies. Thus, an increase in airway calibre is unlikely to be the explanation for the reduced responses to histamine and UNDW challenge after zileuton found in the present study.

Other mechanisms may be considered to explain the observed additive effect of zileuton on BHR, besides ICS, although we did not attempt to explore these possibilities. It might be postulated that zileuton has, besides ICS, an additional inhibitory effect on the activation of the 5-lipoxygenase pathway. Such action would explain the increase in PD20,UNDW by an inhibitory action on leukotriene $(\mathrm{LT}) \mathrm{C}_{4}, \mathrm{LTD}_{4}$ and $\mathrm{LTE}_{4}$ production induced by osmolar changes. Indeed, UNDW appears to induce leukotriene production. MEsLIER et al. [30] showed that intranasal installation of distilled water aerosol in responsive subjects with allergic rhinitis raised the humoral and cellular content of nasal lavage fluid, including $\mathrm{LTB}_{4}$ and $\mathrm{LTD}_{4}$, to a similar extent as after allergen challenge. In contrast, there is no evidence that post-histamine-induced responses might be mediated by leukotrienes. Histamine provocation did not provoke release of leukotrienes [31]. Nevertheless, it cannot be excluded that patients with still significant BHR despite ICS are those in whom bronchoconstriction is, in part, dependent on leukotrienes. Another potential explanation is that zileuton might act, in part, as an antihistamine. This could explain the effects on histamine reactivity as well as a smaller effect on UNDW. However, to our knowledge pharmacological data to support this concept are not available. Clearly, subsequent studies are required to explore the above-men- 
tioned possibilities.

Finally, a potential order effect associated with tachyphylaxis should be considered. In this study, measurements were performed with an interval of at least 5 days. This study design was chosen since it is known that histamine provocation may induce a significant bronchoconstriction response to UNDW [17]. Tachyphylaxis for repeated histamine provocations may exist, as does refractoriness for UNDW, which may persist up to $4 \mathrm{~h}$ [17]. The half-life of zileuton is $2.5 \mathrm{~h}$, and its effect on 5 -lipoxygenase activity should have been dissipated less than $16 \mathrm{~h}$ postingestion [11]. Looking at table 3, however, no order effect appeared to be present.

In conclusion, although the number of patients studied was small, the present data show that a single dose of $400 \mathrm{mg}$ zileuton may attenuate bronchial hyperresponsiveness in steroid-dependent asthmatics. Additional studies are necessary to investigate whether similar effects are found after prolonged periods of treatment with zileuton.

\section{References}

1. Barnes PJ. Inhaled glucocorticoids for asthma. $N$ Engl J Med 1995; 332: 868-875.

2. Kamada AK, Szefler SJ, Martin RJ, et al. Issues in the use of inhaled glucocorticoids. Am J Respir Crit Care Med 1996; 153: 1739-1748.

3. Tagari P, Brideau C, Chan C, Frenette R, Black C, Ford Hutchinson A. Assessment of the in vivo biochemical efficacy of orally active leukotriene biosynthesis inhibitors. Actions Agents 1993; 40: 62-71.

4. Bell RL, Lanni C, Malo PE, et al. Preclinical and clinical activity of zileuton and A-78773. Ann NY Acad Sci 1993; 696: 205-215.

5. Drazen JM, Israel E. Treatment of chronic stable asthma with drugs active on the 5-lipoxygenase pathway. Int Arch Allergy Immunol 1995; 107: 319-320.

6. McGill KA, Busse WW. Zileuton. Lancet 1996; 348: 519-524.

7. Israel E, Dermarkarian R, Rosenberg M, et al. The effects of a 5-lipoxygenase inhibitor on asthma induced by cold, dry air. $N$ Engl J Med 1990; 323: 1740-1744.

8. Hui KP, Taylor IK, Taylor GW, et al. Effect of a 5lipoxygenase inhibitor on leukotriene generation and airway responses after allergen challenge in asthmatic patients. Thorax 1991; 46: 184-189.

9. Israel E, Fischer AR, Rosenberg MA, et al. The pivotal role of 5-lipoxygenase products in the reaction of aspirin-sensitive asthmatics to aspirin. Am Rev Respir Dis 1993; 148: 1447-1451.

10. Meltzer SS, Hasday JD, Cohn J, Bleecker ER. Inhibition of exercise-induced bronchospasm by zileuton: a 5-lipoxygenase inhibitor. Am J Respir Crit Care Med 1996; 153 : 931-935.

11. Fischer AR, McFadden CA, Frantz R, et al. Effect of chronic 5-lipoxygenase inhibition on airway hyperresponsiveness in asthmatic subjects. Am J Respir Crit Care Med 1995; 152: 1203-1207.

12. Israel E, Rubin P, Kemp JP, et al. The effect of inhibition of 5-lipoxygenase by zileuton in mild-to-moderate asthma. Ann Intern Med 1993; 119: 1059-1066.

13. Israel E, Cohn J, Dube L, Drazen JM. Effect of treatment with zileuton, a 5-lipoxygenase inhibitor, in patients with asthma: a randomized controlled trial. Zileuton Clinical Trial Group. JAMA 1996; 275: 931-936.

14. American Thoracic Society. Standards for the diagno- sis and care of patients with chronic obstructive pulmonary disease (COPD) and asthma. Am Rev Respir Dis 1987; 136: 225-244.

15. Kerstjens HAM, Brand PLP, Hughes MD, et al. A comparison of bronchodilator therapy with or without inhaled corticosteroid therapy for obstructive airways disease. N Engl J Med 1992; 327: 1413-1419.

16. Quanjer PH. Standardized Lung Function Testing. Report Working Party "Standardization of Lung Function Tests" of the European Respiratory Society and the European Coal and Steel Community. Eur Respir J 1993; 6 (Suppl.16): 1-100.

17. Groot CAR, Lammers JW, Festen J, van Herwaarden CLA. Refractoriness for ultrasonically nebulized distilled water and histamine after histamine challenge. $J$ Appl Physiol 1991; 70: 1011-1015.

18. Bootsma GP, Dekhuijzen PNR, Festen J, Mulder P, van Herwaarden CLA. Comparison of fluticasone propionate and beclomethasone dipropionate on direct and indirect measurements of bronchial hyperresponsiveness in patients with stable asthma. Thorax 1995; 50: 1044-1050.

19. Rubin P, Dube L, Braeckman R, et al. Pharmacokinetics, safety, and ability to diminish leukotriene synthesis by zileuton, an inhibitor of 5-lipoxygenase. Agents Actions Suppl 1991; 35: 103-116.

20. Cockcroft DW, Killian DN, Mellon JA, Hargreave FE. Bronchial reactivity to inhaled histamine; a method and clinical survey. Clin Allergy 1977; 7: 235-243.

21. Norusis MJ. In: SPSS/PC+ 5.0 Base Manual. Chicago, SPSS Inc., 1992

22. Pocock SJ. In: Clinical Trials: a Practical Approach. Chisester, Wiley \& Sons, 1983.

23. Pauwels R, Joos G, Van der Straeten M. Bronchial hyperresponsiveness is not bronchial hyperresponsiveness is not asthma. Clin Allergy 1988; 18: 317-321.

24. Anderson SD, Smith CM. Osmotic challenges in the assessment of bronchial hyperresponsiveness. Am Rev Respir Dis 1991; 143 (Suppl.): S43-S46.

25. Mattoli S, Forensi A, Corbo GM, Valente S, Patalano $\mathrm{F}$, Ciappi G. Increase in bronchial responsiveness to methacholine and late asthmatic response after inhalation of ultrasonically-nebulized distilled water. Chest 1986; 90: 726-732.

26. Bussieres S, Turcotte H, Boulet LP. Hyperosmolarityinduced increases in airway responsiveness and late asthmatic responses. Eur Respir J 1991; 4: 290-295.

27. Groot CAR, Lammers JW, Molema J, Festen J, van Herwaarden CLA. Effect of inhaled beclomethasone and nedocromil sodium on bronchial hyperresponsiveness to histamine and distilled water. Eur Respir J 1992; 5: 1075-1082.

28. Barnes PJ, Pedersen S. Efficacy and safety of inhaled corticosteroids in asthma. Am Rev Respir Dis 1993; 148 (Suppl.): S1-S26.

29. Fujimura M, Sakamoto S, Kamio Y, Matsuda T. Effect of a leukotriene antagonist, ONO-1078, on bronchial hyperresponsiveness in patients with asthma. Respir Med 1993; 87: 133-138.

30. Meslier N, Braunstein G, Lacronique J, et al. Local cellular and humoral responses to antigenic and distilled water challenge in subjects with allergic rhinitis. $A m$ Rev Respir Dis 1988; 137: 617-624.

31. Kumlin M, Dahlen B, Bjorck T, Zetterstrom O, Granstrom $E$, Dahlen SE. Urinary excretion of leukotriene $\mathrm{E}_{4}$ and 11-dehydro-thromboxane $\mathrm{B}_{2}$ in response to bronchial provocations with allergen, aspirin, leukotriene $\mathrm{D}_{4}$, and histamine in asthmatics. Am Rev Respir Dis 1992; 146: 